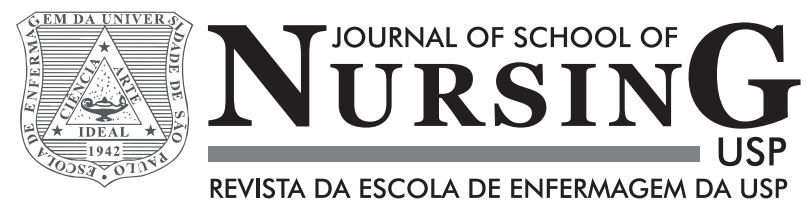

\title{
Clinical reasoning in undergraduate nursing education: a scoping review
}

\author{
Raciocínio clínico no ensino de graduação em enfermagem: revisão de escopo \\ Razonamiento clínico en la enseñanza de licenciado en enfermería: revisión de blanco
}

\author{
Sáskia Sampaio Cipriano de Menezes ${ }^{1,2}$, Consuelo Garcia Corrêa ${ }^{3}$, Rita de Cassia Gengo e Silva ${ }^{3}$, Diná de Almeida \\ Monteiro Lopes da Cruz ${ }^{3}$
}

\footnotetext{
${ }^{1}$ Universidade de São Paulo, Escola de Enfermagem, São Paulo, SP, Brazil.

${ }^{2}$ Universidade Federal do Amazonas, Escola de Enfermagem, Manaus, AM, Brazil.

${ }^{3}$ Universidade de São Paulo, Escola de Enfermagem, Departamento de Enfermagem Médico-Cirúrgica, São Paulo, SP, Brazil.
}

\begin{abstract}
Objective: This study aimed at analyzing the current state of knowledge on clinical reasoning in undergraduate nursing education. Methods: A systematic scoping review through a search strategy applied to the MEDLINE database, and an analysis of the material recovered by extracting data done by two independent reviewers. The extracted data were analyzed and synthesized in a narrative manner. Results: From the 1380 citations retrieved in the search, 23 were kept for review and their contents were summarized into five categories: 1) the experience of developing critical thinking/clinical reasoning/decision-making process; 2) teaching strategies related to the development of critical thinking/clinical reasoning/decision-making process; 3) measurement of variables related to the critical thinking/clinical reasoning/decision-making process; 4) relationship of variables involved in the critical thinking/clinical reasoning/decisionmaking process; and 5) theoretical development models of critical thinking/clinical reasoning/decision-making process for students. Conclusion: The biggest challenge for developing knowledge on teaching clinical reasoning seems to be finding consistency between theoretical perspectives on the development of clinical reasoning and methodologies, methods, and procedures in research initiatives in this field.
\end{abstract}

\section{DESCRIPTORS}

Decision Making; Nursing; Education, Nursing; Review. 


\section{INTRODUCTION}

Constant changes in healthcare systems and the continued increase in the complexity of health problems has required the development, improvement and mastering of intellectual, interpersonal and technical abilities of professionals to make clinical decisions compatible with safe effective practices, thus being able to produce desirable health outcomes ${ }^{(1-3)}$. Although there is a considerable volume of productions on clinical reasoning, clinical judgment or decision-making, very few of the available evidence is applicable to educational initiatives aimed at developing clinical reasoning for future professionals ${ }^{(4)}$.

Clinical reasoning is a generic term that is commonly referred to as the processes through which information is obtained and interpreted to draw the necessary conclusions for health care. However, other expressions are used interchangeably with clinical reasoning, such as clinical judgment, decision-making process or even critical thinking ${ }^{(5-6)}$. Regardless, clinical reasoning is a primary skill in nursing practice because it is through it that professionals identify, prioritize, and establish plans, as well as interpret clinical data ${ }^{(2)}$.

It can be assumed that research on clinical reasoning in nursing is quite extensive and has a certain tradition, but its outlines are still unclear; and especially with regard to the development of clinical reasoning in nursing students, clinical reasoning is little explored. This article constitutes a report of a scoping review in order to analyze the current state of knowledge on clinical reasoning, decision-making and critical thinking in undergraduate nursing education. More specifically, it seeks to answer the following question: What is being studied on the clinical reasoning/critical thinking/ decision-making process in undergraduate nursing education?

This study aimed at analyzing the current state of knowledge on clinical reasoning in nursing undergraduate education.

\section{METHOD}

This study was designed as a scoping review. A scoping study or scoping review aims to map the key concepts that support a particular area of knowledge, examining its extent, scope and nature of the investigation, summarizing and disseminating research data and identifying existing research gaps ${ }^{(7)}$. Empirical and theoretical studies published in English, Spanish or Portuguese were included, which involved participants or subjects of interest to undergraduate nursing students, regardless of the program having characteristics of a generic baccalaureate degree or to train/graduate nurses in specific areas (for example, obstetrics, mental health), similar to what occurs in some other countries. The contexts of interest were any settings related to undergraduate nursing education.

To construct the search strategies we used an adaptation of the PICO strategy (P: patient, I: intervention, C: comparison, O: outcomes). The PICO strategy guides the development of the research question and the literature search, and allows the professional or researcher to accurately locate the best available scientific information ${ }^{(8)}$.
Considering the question of the review mentioned above, the literature search of articles was guided by PICO adapted to PIC, with "P" being population (nursing students and nurses), "I" the phenomenon of interest (clinical reasoning), and " $\mathrm{C}$ "context (nursing education). The descriptors and combinations used to construct strategies were: "nurses"; "nursing staff"; "students, nursing"; "clinical competence"; "judgement”; "intuition"; "thinking”; "diagnosis, differential"; "cognition"; "logic"; "cognitive science"; "decision theory"; "decision support systems, "clinical"; "decision support techniques"; "nursing diagnosis"; "education"; "hospitals"; "learning”; "nurse's practice patterns"; "nursing care"; "nursing faculty practice"; "patient care planning"; "preceptorship"; "problem-based learning"; "schools", "health occupations"; "teaching"; "hospitals", "teaching"; "universities". The search was conducted in the MEDLINE (PubMed) database, from its inception until October 2014 when it was completed, and was limited only to articles published in Portuguese, English or Spanish.

When available, the titles and abstracts of articles retrieved in the search were read and analyzed by one of the reviewers (SCCM) to identify those potentially eligible for the study. In situations of doubt, the articles were kept for the next phase, which involved reading each of the articles selected by two independent reviewers in full to: a) confirm the relevance to the review question and, if so, b) extract the data of interest. The four authors of this review participated in this phase, and situations of doubt were resolved by a consensus meeting. Scoping reviews do not allow for article exclusion according to methodological quality criteria, but in order to support the synthesis of data, the items kept in this review were submitted to the evaluation of methodological quality by the Joanna Briggs Institute instruments ${ }^{(9)}$, and by the Cosmin Checklist ${ }^{(10)}$ in the case of instrument validation studies.

Data were extracted by one reviewer, confirmed by a second reviewer and inconsistencies or concerns were resolved by consensus between all authors. Publication characterization data (year, location, and journal, for example) were extracted, along with type of publication content (empirical or theoretical study); and in the case of empirical study, the design and characteristics of the participants. In each publication, the main focus involved in the problem of study, in its arguments, its methods (in the case of empirical studies), its discussions and conclusions were identified and extracted. The main focuses were analyzed by going back to the full texts when necessary, from which analysis categories were then identified that allowed for synthesizing the findings in a narrative manner.

\section{RESULTS}

The search strategies retrieved 1380 records, with one article being replicated. The titles and abstracts were read and analyzed to select articles that were relevant to the review question and resulted in keeping 38 articles, which had themes of clinical reasoning, critical thinking and decisionmaking in nursing (being the phenomenon of interest for this study). Of these, 23 articles were selected by full reading 
because they specifically addressed undergraduate nursing education. Figure 1 describes the flow of analysis.

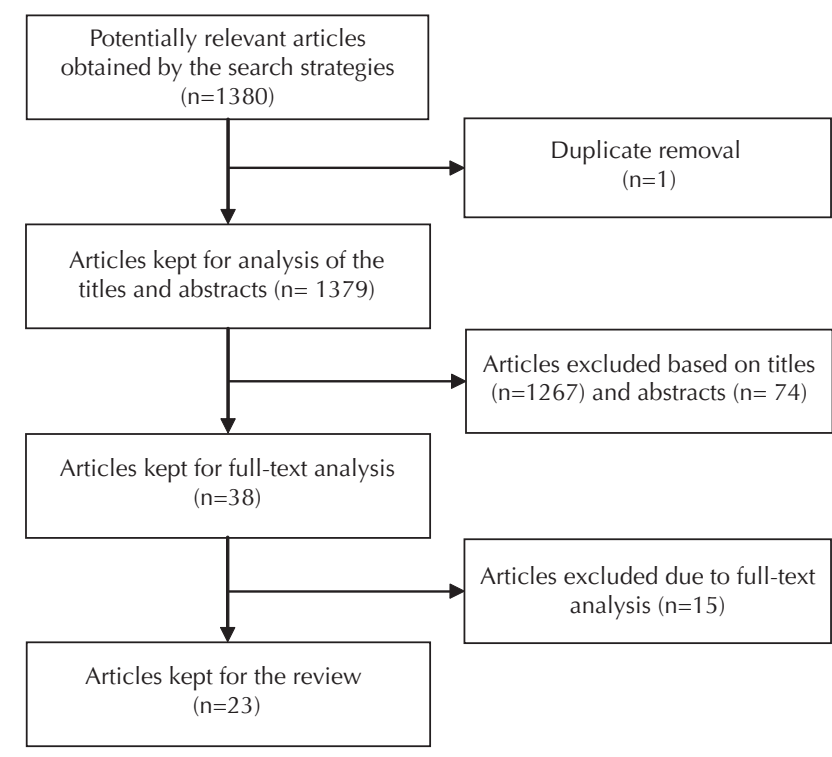

Source: Research data.

Figure 1 - Flow diagram of literature search and inclusion of articles.

The 23 publications included in the review for fulltext analysis were conducted between the years 1993 and 2013; 13 (56.5\%) were published in the United States, three (13.0\%) in the UK and one (4.4\%) in each of the following countries: Norway, Spain, Scotland, Canada, Turkey, Taiwan and Korea. Table 1 describes the distribution of publications regarding the type of study and methodology.

Table 1 - Distribution of publications regarding type of study and methodology - Manaus, AM, Brazil, 2015.

\begin{tabular}{lcc}
\hline Type of study and methodology & N & \%* \\
\hline 1. Empirical (type) & 14 & 51.8 \\
1.1 Qualitative (design) & 5 & 21.8 \\
Content analysis & 2 & 8.7 \\
Ethnography & 1 & 4.3 \\
Action research & 1 & 4.3 \\
Grounded theory & 1 & 4.3 \\
\hline 1.2 Quantitative (design) & 9 & 39.1 \\
Cross-sectional / Analytical & 3 & 11.1 \\
Methodological development & 2 & 8.7 \\
Quasi-experimental (before and after) & 2 & 8.7 \\
Quasi-experimental with non-randomized & 1 & 4.3 \\
control group & 1 & 4.3 \\
Cohort & 9 & 39.1 \\
\hline 2. Theoretical (type) & 4 & 17.4 \\
2.1 Case studies (design) & 3 & 11.1 \\
2.2 Opinion (design) & 2 & 8.7 \\
2.3 Review (design) & 23 & 100 \\
\hline Total & & \\
\hline Note: Ne23) & &
\end{tabular}

Note: $(\mathrm{N}=23)$

The sample sizes of 14 empirical studies ranged from 18 to 446 , with a total number of 2146 nursing students. These students were undergraduates in Bachelor of Nursing and Obstetrics' programs.

Full-text analysis of the 23 articles included enabled identifying the main focuses of interest in each publication, which were then organized into categories and subcategories, as shown in Table 2 .

Table 2 - Main focus of the studies analyzed on clinical reasoning in undergraduate Nursing education - Manaus, AM, Brazil, 2015.

\begin{tabular}{|c|c|c|c|}
\hline \multirow{2}{*}{ Categories and subcategories } & \multicolumn{3}{|c|}{ Type of study } \\
\hline & Empirical & Theoretical & Total \\
\hline $\begin{array}{l}\text { Teaching strategies related to the } \\
\text { development of clinical reasoning/ } \\
\text { decision-making/critical thinking }\end{array}$ & 2 & 6 & 8 \\
\hline $\begin{array}{l}\text { Strategies for developing critical } \\
\text { thinking }{ }^{(3,11-16)}\end{array}$ & 2 & 5 & 7 \\
\hline $\begin{array}{l}\text { Strategies for developing clinical } \\
\text { reasoning }\end{array}$ & - & 1 & 1 \\
\hline $\begin{array}{l}\text { Relationship of variables involved } \\
\text { in clinical reasoning/decision- } \\
\text { making/critical thinking }\end{array}$ & 4 & 1 & 5 \\
\hline Development of critical thinking ${ }^{(18)}$ & 1 & - & 1 \\
\hline $\begin{array}{l}\text { Relationship between the } \\
\text { curriculum and critical thinking/ } \\
\text { Development of critical thinking }{ }^{(19)}\end{array}$ & 1 & - & 1 \\
\hline $\begin{array}{l}\text { Relationship between thinking } \\
\text { styles and creativity }{ }^{(2))}\end{array}$ & 1 & - & 1 \\
\hline $\begin{array}{l}\text { Relationship between reflective } \\
\text { skills and sense of coherence } \\
\text { between theory and practice by } \\
\text { students }^{(21)}\end{array}$ & 1 & - & 1 \\
\hline $\begin{array}{l}\text { Relationship between critical } \\
\text { thinking and performance } \\
\text { in professional accreditation } \\
\text { examinations (NCLEX-RN) }{ }^{(22)}\end{array}$ & - & 1 & 1 \\
\hline $\begin{array}{l}\text { The experience of developing } \\
\text { clinical reasoning/decision- } \\
\text { making/critical thinking }\end{array}$ & 3 & 1 & 4 \\
\hline $\begin{array}{l}\text { Learn how to make clinical } \\
\text { decisions (factors that favor/ } \\
\text { encourage or discourage/disfavor; } \\
\text { conditions in which learning } \\
\text { occurs) }^{(23)}\end{array}$ & 1 & - & 1 \\
\hline Development of critical thinking(24) & - & 1 & 1 \\
\hline $\begin{array}{l}\text { Understanding the experience } \\
\text { of developing critical thinking, } \\
\text { clinical reasoning and problem } \\
\text { solving }\end{array}$ & 1 & - & 1 \\
\hline $\begin{array}{l}\text { Situations/contexts that demand } \\
\text { critical thinking }^{(26)}\end{array}$ & 1 & - & 1 \\
\hline $\begin{array}{l}\text { Measurement of variables related } \\
\text { to the clinical reasoning/decision- } \\
\text { making/critical thinking }\end{array}$ & 3 & - & 3 \\
\hline Measurement of intuition ${ }^{(27-28)}$ & 2 & - & 2 \\
\hline Measurement of critical thinking ${ }^{(29)}$ & 1 & - & 1 \\
\hline $\begin{array}{l}\text { Theoretical model of the } \\
\text { development of clinical reasoning/ } \\
\text { decision making/critical thinking }\end{array}$ & 2 & 1 & 3 \\
\hline $\begin{array}{l}\text { Model of mental schemata } \\
\text { construction for the development } \\
\text { of skills in solving problems } \\
\text { concerning calculating medicine } \\
\text { dosages }^{(30)}\end{array}$ & 1 & - & 1 \\
\hline
\end{tabular}


...continuation

\begin{tabular}{lccc}
\hline \multirow{2}{*}{ Categories and subcategories } & \multicolumn{3}{c}{ Type of study } \\
\cline { 2 - 4 } & Empirical & Theoretical & Total \\
\hline $\begin{array}{l}\text { Model of relationship between } \\
\text { variables that contribute to critical } \\
\text { thinking }\end{array}$ & - & 1 & 1 \\
Decision-making model & & & \\
\hline Total & 1 & - & 1 \\
\hline Note: $(\mathrm{N}=23)$. & 14 & 9 & 23 \\
\hline
\end{tabular}

The focus categories are shown below through thematic analysis.

\section{TEACHING STRATEGIES RELATED TO THE DEVELOPMENT OF CLINICAL REASONING/CRITICAL THINKING}

This thematic category was predominant with eight studies (Table 2). Among the strategies identified in the studies we have: mobile web-based learning technology $\mathrm{y}^{(3)}$, critical appraisal exercises ${ }^{(11)}$, SAC learning tool (Structured Academic Controversy) ${ }^{(12)}$, mind-mapping tool ${ }^{(13)}$, learning activities based on the concept ${ }^{(14)}$, the genogram, scenarios based on community health practices ${ }^{(15-16)}$ and clinical simulations of emergency situations ${ }^{(17)}$.

Empirical studies have proposed to evaluate the effect of strategies or instruments on the development of reasoning and critical thinking of nursing students. In one study, the authors concluded that the concept-based learning activities have a positive influence on the development of clinical judgement, as evaluated by Lasater Clinical Judgment Rubric $^{(14)}$. In another study, improvement in critical thinking was observed as evaluated by the Watson-Glaser Critical Thinking Appraisal (WGCTA) after a community health course based on scenarios ${ }^{(16)}$.

The theoretical articles reported all the teachinglearning experiences as being successful in the authors' opinion $^{(3,11-13,17)}$. The experiences reported were: using mobile technology in clinical practice to promote critical thinking of nursing students ${ }^{(3)}$, teaching and practicing critical appraisal of research as an opportunity to develop transferable skills for critical thinking ${ }^{(11)}$; the experience of structured debate mediated by the teacher creating the opportunity for students to explore different care perspectives in decision-making on issues related to nursing care $^{(12)}$; the use of mind mapping strategy to develop critical thinking skills when planning patient care ${ }^{(13)}$; using clinical emergency simulations for developing the students' clinical reasoning skills ${ }^{(17)}$.

\section{RELATIONSHIP OF VARIABLES INVOLVED IN THE CRITICAL THINKING/CLINICAL REASONING/DECISION- MAKING PROCESS}

The five studies that made up the relationship category of variables involved in critical thinking/clinical reasoning and decision-making process (Table 2) analyzed the following relationships between variables: demographic and development of skills in critical thinking ${ }^{(18)}$; critical thinking skills after curriculum revision ${ }^{(19)}$; thinking styles and creativity ${ }^{(20)}$; reflective skills and consistency between theory and practice ${ }^{(21)}$; and performance in professional accreditation exams ${ }^{(22)}$.

The Critical Thinking Skills Test (CCTST) was used in two studies ${ }^{(18-19)}$. In one study, three types of baccalaureate curriculum were compared (traditional bachelor's degree, accelerated curriculum and license) to assess critical thinking entering and exiting the programs ${ }^{(18)}$. The results showed significant improvement in critical thinking in all three groups $^{(18)}$. In another study that also used the CCTST, the authors were concerned about seeing if the implementation of a focused curriculum to promote critical thinking would result in critical thinking differences between students of the original curriculum and the revised curriculum, and additionally they assessed changes in critical thinking during the bachelor's degree program ${ }^{(19)}$. Three cohorts of students (one of the original curriculum and the first two cohorts of the revised curriculum) were evaluated at the beginning, middle and end of the program; students in the first cohort of the revised curriculum performed better than the original curriculum, which did not occur with the students of the second cohort of the revised curriculum ${ }^{(19)}$. Improvement in critical thinking was only observed in the first group of the revised curriculum; in the original curriculum class there was no change over time, and the second group of the revised curriculum worsened ${ }^{(19)}$. The authors attributed these results to the possible lack of CCTST specificity for nursing and the particular characteristics of each class/ group of students ${ }^{(19)}$.

A study in Spain explored associations between the styles of thinking and creativity in a group of nursing professionals and students through the Spanish Test of Creative Intelligence (CREA) and the Thinking Styles Inventory (TSI) ${ }^{(20)}$. The results identified two profiles: the nursing professional and the nursing student. It highlighted the characteristic that students like to judge and evaluate policies and procedures, and another important difference is in their legislative thinking style, the style with the most creative feature, which was more prevalent in students than in nurses. The authors emphasize the need to encourage the legislative style of thinking among students in the professional field, which may promote innovation and creativity $^{(20)}$

In a study on the development of reflective skills by nursing students, the authors investigated how these skills are acquired, how they influence the perception of consistency between the theoretical and practical components, and how practical skills and theoretical knowledge affect the reflective skills of students ${ }^{(21)}$. Results indicated that nursing education can improve the ability of nursing students to perceive coherence between theory and practice through the development of reflective skills ${ }^{(21)}$.

A review article analyzed the results of quantitative research relevant for the assessment of critical thinking skills in undergraduate nursing students and the use of critical thinking as a performance predictor in the National Council Licensure Examination-Registered Nurse (NCLEX$\mathrm{RN}$ ), a professional accreditation nursing exam applied in the United States ${ }^{(22)}$. The review pointed out that critical 
thinking measurement instruments are adaptations of tools not specific to nursing, which would explain the inconsistent results regarding the reliability of the instruments that assess critical thinking skills in the study groups and no relation to NCLEX-RN ${ }^{(22)}$.

\section{THE EXPERIENCE OF DEVELOPING CRITICAL THINKING/ CLINICAL REASONING/DECISION-MAKING}

In the analyzed studies, the contexts of critical thinking development were classroom and clinical settings (obstetrics and psychiatry) ${ }^{(23-26)}$. Students were investigated: in their decision making, and the factors that help or interfere in this process were analyzed ${ }^{(23)}$; in the available evidence on the development of nursing students' critical thinking through problem-based learning ${ }^{(24)}$; in the understanding that they develop cognitive skills from their experiences ${ }^{(25)}$ and in identifying critical thinking contexts during clinical practice in psychiatry units ${ }^{(26)}$.

The findings of the studies indicated that to improve the learning environment in the classroom, the participation of nursing mentors and tutoring support in the clinical practice fields ${ }^{(23-24)}$, the students' understanding of the importance of cognitive skills in their own training ${ }^{(25)}$, thus promoting reflection by the students about themselves, their actions, personal feelings and student-patient relationships ${ }^{(26)}$ are necessary conditions for developing the process of decisionmaking in nursing education. The development of critical thinking in the context of problem-based learning is still controversial $^{(24)}$.

\section{Measurement of Variables Related to the CRITICAL THINKING/CLINICAL REASONING/DECISION- MAKING PROCESS}

Three studies aimed at measuring some variable related to clinical reasoning ${ }^{(27-29)}$. One study estimated the psychometric properties of an intuition instrument and clarified the factors found in the first psychometric assessment ${ }^{(27)}$. Another study tested the validity and the reliability of the Turkish version of a scale of nursing students use of intuition ${ }^{(28)}$, and the third study was conducted to evaluate how critical thinking tests reflect the mastery of this skill and if its scores reflect the role of nursing programs in the development of critical thinking(29). Psychometric evaluation of the intuition instrument examined its stability and the revision of the items showed construct validity and reliability for measuring the students' dimensions of intuition ${ }^{(27)}$. The use of intuition instruments in the studies ${ }^{(27-28)}$ led us to conclude that intuitive abilities nourish the promotion of holistic care $^{(29)}$, helping students become aware of using intuition as part of the nursing process and also reaffirming the relationship between critical thinking, cognitive development and the ability of intuitive decision-making ${ }^{(27)}$. In the Turkish version of the intuition instrument, variables such as culture, ethnicity, type of healthcare systems and curricular differences influenced the capacity for insight and intuitive decision-making ${ }^{(28)}$.
The CCTST (Critical Thinking Skills Test) and the CTDI (California Critical Thinking Disposition Inventory) instruments were applied in a study that sought to investigate the extent to which the tests consistently reflect the critical thinking domain, and how their results are used to evaluate nursing programs. The findings showed that the traits measured by the CCTDI do not relate to critical thinking skills. If the empirical evidence does not support using scores of a general measure to assess the critical thinking of nursing students, nursing programs may need to reexamine how critical thinking should be assessed ${ }^{(29)}$.

\section{THEORETICAL MODEL OF THE DEVELOPMENT OF CRITICAL THINKING/CLINICAL REASONING/DECISION-MAKING}

Three studies focused structures or theoretical models related to clinical reasoning (Table 2$)^{(30-32)}$. In one, the authors derived an explanatory theory from data obtained in previous studies about how the virtual environments of high-fidelity and simulated clinical settings support the construction of mental schemata and cognitive development necessary to solve calculation problems of medication dosage ${ }^{(30)}$. The authors took students' experiences and evaluations on the development of problem-solving skills for drug dosage calculation problems in lectures as data to support the theory, as well as using the Medication Dosage Calculation Problem-Solving program (MDC-PS), a prototype of an authentic atmosphere for drug dosage calculation ${ }^{(30)}$. The construction of an accurate mental exercise for developing problem-solving skills for calculating medication dosage is supported by two factors: 1 ) in the meaning situated by an authentic visualization of the set of competencies required for calculating medication dosage; 2) in the increase of comfort, confidence and competence achieved through practicing in a protected environment ${ }^{(30)}$. The authors conclude that educational programs that use such virtual environments of highfidelity and simulated clinical settings provide a solid framework for a diagnostic evaluation of learning these critical skills in solving medication calculation problems $(\mathrm{MDC}-\mathrm{PS})^{(30)}$.

In an opinion article ${ }^{(31)}$, a critical thinking development model among nursing students was proposed considering the subprocesses of knowledge to explain the relationship between variables contributing to critical thinking. The model explains the relationship between the experiences of the students in their learning environments on how it influences the development of critical thinking, once it is manifested in the clinical trial ${ }^{(31)}$. The author emphasizes that research should be conducted to understand how the teaching-learning experience can contribute to the development of critical thinking measures among nursing students, and also suggests that educational interventions might be implemented to promote reflection and contribute to expressing the main elements of critical thinking among students ${ }^{(31)}$.

In a study that aimed at understanding the relationship between perception and judgment in clinical decision- 
making, a theoretical model has been proposed to provide a holistic educational approach to clinical decision-making ${ }^{(32)}$. This model, called Brooks' theory of intrapersonal perceptual awareness, has been derived from the conceptual model by King on the interaction of personal, interpersonal and social systems, with the central premise that the nurse is a whole, and he/she moves as a whole in clinical situations and makes clinical decisions ${ }^{(32)}$. The central category of the theoretical model is the self, the expression of inseparable interaction between perception and judgment, since it is through this interrelationship of nurses' intrapersonal characteristics that he/she, as a whole, make clinical decisions ${ }^{(32)}$. The proposed model is described as: the intrapersonal characteristics (beliefs, values, education, experience, religion, socio-cultural factors) interacting in the intrapersonal processes of consciousness of perception (sensory, intuitive) and judgment (cognitive, affective) through the self in clinical settings ${ }^{(32)}$. So the self is the basis for learning how to make clinical decisions and to teach students to make such decisions ${ }^{(32)}$.

\section{DISCUSSION}

Mapping the literature related to knowledge produced on clinical reasoning, decision-making and critical thinking in teaching undergraduate nursing allowed for knowing the concerns, needs and challenges facing researchers and specialists in this area. The majority of studies addressed issues of critical thinking, decisionmaking and problem solving, but there were few studies on the clinical reasoning in undergraduate courses. Studies on clinical decision-making in nursing education remain underexplored, keeping in mind the complexity of the process $^{(2)}$.

Teaching and learning strategies were the most common topic among studies (Table 2), which, on the one hand is positive for showing concern in producing knowledge to guide the teaching of such important skills, but on the other, it would be expected that research would be based on more or less organized conceptual models, which was not observed. However, strategies and teaching tools involved in the studies of this review were derived from more active perspectives of education. Generally speaking, it can be assumed that the results converge in order to support the idea that clinical experience is indispensable for developing clinical reasoning ${ }^{(3,11-17)}$. However, current difficulties to ensure undergraduate students exposure to clinical settings of appropriate duration, diversity and quality ${ }^{(33)}$ have limited such opportunities, which certainly has important consequences on the development of clinical reasoning of young professionals.

Teaching-learning experiences in the development of clinical reasoning, critical thinking and decisionmaking described in an undergraduate training context was the second most frequent category in the included studies (Table 2). The thematic focus shows the concern in educational conditions conducive to the development of critical thinking skills. This is especially apparent when taken from the student's perspective, identifying such conditions as a starting point for creating strategies for the full development of clinical reasoning/critical thinking/ clinical decision-making becomes essential.

Studies measuring variables related to clinical reasoning, critical thinking and decision-making used intuition instruments to develop tools that promote the self-awareness of students ${ }^{(27-28)}$. Knowing the intuitive capabilities of students and understanding how they assess the role of intuition in clinical decision-making directs how to work with intuition in the curricula, relating it to other concepts of critical thinking, clinical reasoning and decision-making. Studies on the relationship between these concepts will advance the knowledge and practices for developing clinical reasoning in nursing education.

Proposed theoretical development models of clinical reasoning, critical thinking and decision-making ${ }^{(30-32)}$ attempt to explain how development of problem solving skills, critical thinking and clinical reasoning can be done. Theoretical bases supported the discussed models, but they still require tests to estimate their validity in samples of students and / or nurses to better understand the teaching-learning experiences that contribute to the development of clinical reasoning and critical thinking among nursing students.

The definition of clinical reasoning is often associated with critical thinking, clinical judgment and decisionmaking ${ }^{(6)}$, without making it explicit to the reader which adopted understanding of the concept it is within each study. This situation by itself weakens the integration of results from different research, which is characterized as one of the limitations of this study. It must be considered that the related terms of clinical reasoning, critical thinking and decision-making can bring forth research results of heterogeneous focuses in the research.

Challenges for future studies are in developing knowledge on the clinical reasoning in education and achieving consistency between theoretical perspectives on the development of clinical reasoning and methodologies, methods, and procedures of research initiatives in this field.

\section{CONCLUSION}

This scoping review revealed that the issue of clinical reasoning, critical thinking and decision-making in undergraduate education is relatively little studied. The three terms (clinical reasoning, critical thinking and decision-making) were used as a unit in our decision, by recognizing that they can be used interchangeably. However, if we only had to select clinical reasoning, very few studies on the subject would have been found, considering the perspective of undergraduate teaching/ training. If clinical reasoning is the primary process by which nurses obtain and interpret data to decide on care, one would expect that there would be more research investment to understand this phenomenon and provide evidence to guide teaching and effective learning about the main challenge of nursing care. 


\section{RESUMO}

Objetivo: Este estudo teve como objetivo analisar o estado atual do conhecimento sobre raciocínio clínico no ensino de graduação em enfermagem. Método: Revisão sistemática de escopo mediante estratégia de busca aplicada na base de dados MEDLINE, e análise do material recuperado com extração dos dados por dois revisores independentes. Os dados extraídos foram analisados e sintetizados de forma narrativa. Resultados: Das 1380 citações recuperadas na busca, foram mantidas 23 para a revisão, e seus conteúdos foram sintetizados em cinco categorias: 1) a experiência de desenvolver o pensamento crítico/raciocínio clínico/processo de tomada de decisão; 2) estratégias de ensino relacionadas ao desenvolvimento do pensamento crítico/raciocínio clínico/processo de tomada de decisão; 3 ) mensuração de variáveis relacionadas ao pensamento crítico/raciocínio clínico/processo de tomada de decisão; 4) relacionamento de variáveis envolvidas no pensamento crítico/raciocínio clínico/processo de tomada de decisão; e 5) modelos teóricos de desenvolvimento do pensamento crítico/raciocínio clínico/processo de tomada de decisão por estudantes. Conclusão: O maior desafio para desenvolver o conhecimento sobre o ensino do raciocínio clínico parece ser obter consistência entre as perspectivas teóricas sobre o desenvolvimento de raciocínio clínico e as metodologias, métodos e procedimentos nas iniciativas de pesquisa neste campo.

\section{DESCRITORES}

Tomada de Decisões; Enfermagem; Educação em Enfermagem; Revisão.

\section{RESUMEN}

Objetivo: Este estudio tuvo como objetivo analizar el estado actual del conocimiento sobre razonamiento clínico en la enseñanza durante el licenciado en enfermería. Método: Revisión sistemática de blanco mediante estrategia de búsqueda aplicada en la base de datos MEDLINE y análisis del material recuperado con extracción de los datos por dos revisores independientes. Los datos extraídos fueron analizados y sintetizados de forma narrativa. Resultados: De las 1380 citaciones recuperadas en la búsqueda, fueron mantenidas 23 para la revisión, y sus contenidos fueron sintetizados en cinco categorías: 1) la experiencia de desarrollar el pensamiento crítico/ razonamiento clínico/proceso de toma de decisión; 2) estrategias de enseñanza relacionadas con el desarrollo del pensamiento crítico/ razonamiento clínico/proceso de toma de decisión; 3) medición de variables relacionadas con el pensamiento crítico/razonamiento clínico/proceso de toma de decisión; 4) relación de variables involucradas en el pensamiento crítico/razonamiento clínico/proceso de toma de decisión; y 5) modelos teóricos de desarrollo del pensamiento crítico/razonamiento clínico/proceso de toma de decisión por estudiantes. Conclusión: El mayor desafío para desarrollar el conocimiento acerca de la enseñanza del razonamiento clínico parece ser obtener consistencia entre las perspectivas teóricas acerca del desarrollo de razonamiento clínico y las metodologías, métodos y procedimientos en las iniciativas de investigación en este campo.

\section{DESCRIPTORES}

Toma de Decisiones; Enfermería; Educación en Enfermería, Revisión.

\section{REFERENCES}

1. Zuriquel Pérez E, Lluch Canut MT, Falcó Pegueroles A, Puig Llobet M, Moreno Arroyo C, Roldán Merino JR. Critical thinking in nursing: scoping review of the literature. Int J Nurs Pract. 2014 May 12. [Epub ahead of print]

2. Fitzpatrick JJ, Smith MJ. Research on clinical decision making: challenges for professional disciplines. Appl Nurs Res. 2013;26(4):161.

3. Lai CY, Wu CC. Supporting nursing students' critical thinking with a mobile web learning environment. Nurse Educ. 2012;37(6):235-6.

4. Thompson TL. The use of evidence in clinical practice decision making. Clin Nurs Spec. 2012;26(5):237-8.

5. Tiffen J, Corbridge SJ, Slimmer L. Enhancing clinical decision making: development of a contiguous definition and conceptual framework. J Prof Nurs. 2014;30(5):399-405.

6. Simmons B. Clinical reasoning: concept analysis. J Adv Nur. 2010;66(5):1151-8.

7. Arksey H, O'Malley L. Scoping studies: towards a methodological framework. Int J Soc Res Meth [Internet]. 2005 [cited 2015 Marc 15];8(1):19-32. Available from: https://www.york.ac.uk/inst/spru/pubs/pdf/Scopingstudies.pdf

8. Santos CMC, Pimenta CAM, Nobre MRC. The PICO strategy for the research question construction and evidence search. Rev Latino Am Enfermagem [Internet]. 2007 [cited 2015 Apr 02];15(3):508-11. Available from: http://www.scielo.br/pdf/rlae/v15n3/v15n3a23.pdf

9. Joanna Briggs Institute. Reviewer's manual: 2014 edition. Adelaide, Australia: JBI; 2014.

10. Mokkink LB, Terweea CB, Patrick DL, Alonso J, Stratford PW, Knol DL et al. The COSMIN study reached international consensus on taxonomy, terminology, and definitions of measurement properties for health-related patient-reported outcomes. J Clin Epidemiol. 2010;63(7):737-45.

11. Whiffin CJ, Hasselder A. Making the link between critical appraisal, thinking and analysis. Br J Nurs. 2013;22(14):831-5.

12. Bull MJ. Using structured academic controversy with nursing students. Nurse Educ. 2007;22(14):218-22.

13. Mueller A, Johnston M, Blig D. Joining mind mapping and care planning to enhance student critical thinking and achieve holistic nursing care. Nurs Diagn. 2002;13(1):24-7.

14. Lasater K, Nielsen A. The influence of concept-based learning activities on students' clinical judgment development. J Nurs Educ. 2009;48(8):441-6.

15. Cascio RS, Campbell D, Sandor MK, Rains AP, Clark MC. Enhancing critical-thinking skill - faculty-student partnerships in community health nursing. Nurse Educ. 1995;20(2):38-43.

16. Sandor MK, Clark M, Campbell D, Rains AP, Cascio R. Evaluating critical thinking skills in a scenario-based community health course. J Community Health Nurs. 1998; 15(1):21-9. 
17. Baldwing KB. Friday night in the pediatric emergency department a simulate exercise to promote clinical reasoning in the classroom. Nurse Educ. 2007;32(1):24-9.

18. Spelic SS, Parsons M, Hercinger M, Andrews A, Parks J, Norris J. Evaluation of critical thinking outcomes of a BSN program. Holist Nurs Pract. 2001;15(3):27-34.

19. Beckie TM, Lowry LW, Barnett S. Assessing critical thinking in baccalaureate nursing students: a longitudinal study. Holist Nurs Pract. 2001;15(3):18-26.

20. Almansa P, López-Martinez O, Corbolán J, Limiñana-Gras RM. Thinking styles and creativity preferences in nursing. Creat Nurs. 2013;19(2):91-100.

21. Hatlevik IKR. The theory-practice relationship: reflective skills and theoretical knowledge as key factors in bridging the gap between theory and practice in initial nursing education. J Adv Nurs. 2011;68(4):868-77.

22. Romeo EM. Quantitative Research on critical thinking and predicting nursing students' NCLEX-RN Performance. J Nurs Educ. 2010;49(7):378-86.

23. Young N. An exploration of clinical decision-making among students and newly qualified midwives. Midwifery. 2012;(28):824-30.

24. Yuan H, Williams BA, Fan L. A systematic review of selected evidence on developing nursing students' critical thinking through problembased learning. Nurse Educ Today. 2008;28(6):657-63.

25. Lake S, Mclnnes R. Exploring cognitive skill development in midwifery education. Nurse Educ Pract. 2012;12(5):264-8.

26. Mun MS. An analysis of narratives to identify critical thinking contexts in psychiatric clinical practice. Int J Nurs Pract. 2010;16(1):75-80.

27. Smith AJ. Continued psychometric evaluation of intuition instrument for nursing students. J Holist Nurs. 2006;24(2):82-9.

28. Demir Y, Denat Y, Khorshid L, Eser I. Cultural validation of the "Use of Intuition by Nursing Students Scale - Turkish version". J Transcult Nurs. 2013;23(4):369-76.

29. Stone CA, Davidson LJ, Evans JL, Hansen MA. Validity evidence for using a general critical thinking test to measure nursing students' critical $^{\prime}$ thinking. Holist Nurs Pract. 2001;15(4):65-74.

30. Weeks KW, Higginson R, Closhesy JM, Coben D. Safety in numbers 7: veni, vidi, duci: A grounded theory evaluation of nursing students' medication problem-solving schemata construction. Nurse Educ Pract. 2013;13(2):78-87.

31. Redding DA. The development of critical thinking among students in baccalaureate nursing education. Holist Nurs Pract. 2001;15(4):57-64.

32. Brooks EM, Thomas S. The perception and judgment of senior baccalaureate student nurses in clinical decision making. ANS Adv Nurs Sci. 1997;19(3):50-69.

33. Niederhauser V, Schoessler M, Gubrud-Howe PM, Magnussen L, Codier E. Creating innovative models of clinical nursing education. J Nurs Educ. 2012;51(11):603-8. 